DOI: 10.26907/2311-2042-2021-16-1-166-171

\title{
RAIS BUKHARAYEV AS A SCHOLAR, TEACHER, AND MENTOR
}

\author{
Dzhavdet Shaukatovich Suleimanov, \\ Applied Semiotics Research Institute, Tatarstan Academy of Sciences, \\ 36 a Levobulachnaya Str., Kazan, 420111, Russian Federation, \\ dvdt.slt@gmail.com.
}

Anis Foatovich Galimyanov, Kazan Federal University, 18 Kremlyovskaya Str., Kazan, 420008, Russian Federation, anis_59@mail.ru.

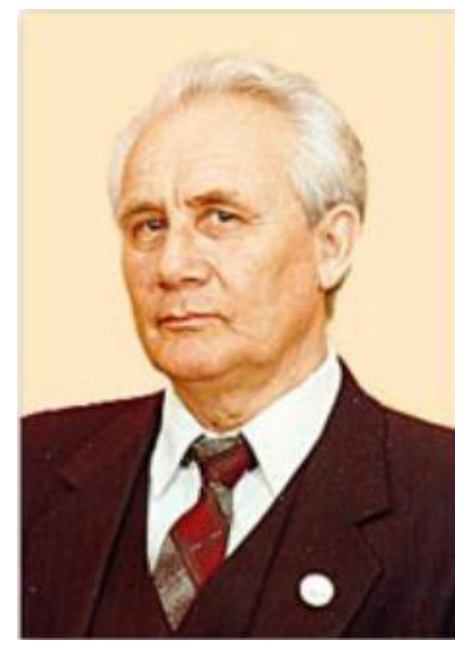

Bukharaev Rais Gataevich (April 24, 1929 - July 31, 2009) was the founder of the School of Mathematical Cybernetics and Informatics of Kazan State University. He was Doctor of Technical Sciences (1968) and Doctor of Physical and Mathematical Sciences (1981), Professor. He was also Honored Scientist of the TASSR, awarded with the badge "Honored Worker of Higher Professional Education of the Russian Federation". He wrote more than 130 scientific papers, including 9 monographs, and had 10 author's certificates for inventions.

His main scientific interest was in the area of the theory of probable automata.
Бохараев Рәис Гата улы (24 апрель, 1929 - 31 июль, 2009) Казан дәүләт университетының математик кибернетика һәм информатика мәктәбенә нигез салучы, техника фәннәре (1968) hәм физика-математика фәннәре (1981) докторы, профессор. ТАССРның атказанган фән эшлеклесе, "РФнең югары профессиональ белем биру почетлы хезмәткәре" билгесе белән бүләкләнгән. 130дан артык фәнни хезмәт, шул исәптән 9 монография авторы, уйлап табуга 10 автор таныклыгы бар.

Төп фәнни тикшеренүләре ихтимали автоматлар теориясе буенча.
Бухараев Раис Гатич (24.04.1929 - 31.07.2009) основатель школы по математической кибернетике и информатике Казанского госуниверситета, доктор технических (1968) и физикоматематических (1981) наук, профессор, Заслуженны деятель науки ТАССР, награжден знаком "Почетный рботник высшего профессионального образования РФ”. Является автором более 130 научных работ, в том числе 9 монографий. Имеет 10 авторсхих свидетельств на изобретение.

Основные научные исследования по теории вероятностных автоматов.
The prominent Tatar scholar R. G. Bukharaev would have turned 91 this year if he had been alive. His scientific legacy has laid the foundation for many scientific works and trends, his numerous disciples keep up the good work.

Bukharaev Rais Gataevich was born on April 24, 1929, in Tomsk. In 1947, he graduated from the $2 d$ School in Kazan and entered the Faculty of Physics and Mathematics of Kazan State University. Since then, his life was inseparably linked to the University.

As a versatile individual, a talented mathematician, and a broad-minded philosopher, his ability to make scientific predictions and his scientific 
perceptions gave Rais Bukharaev a chance to effectively work in a number of new scientific fields, not only at the university, but across the country, and even around the world ([Bukharaev, Kriterii...], [Bukharaev, Veroiatnostnye..., 1970], [Bukharaev, Osnovy...], [Bukharaev, Veroiatnostnye..., 1978], [Bukharaev, Zakharov], [Bukharaev, Instrumental'nye...]). The research and practical work, having started under his guidance in the fields of scientific cybernetics, probabilistic automaton theory, and artificial intelligence, continues successfully today both at Kazan State University and the Tatarstan Academy of Sciences.

Bukharaev started his research work under the guidance of the outstanding professor Norden. In 1955, he presented his Ph.D. dissertation on "The Theory of Biaffin Surfaces and the Theory of Congregation of Biaxyl Spaces" based on his research in the field of geometry. From this moment he would embark on a new field of research - cybernetics. Exactly in the field of mathematical cybernetics and computer sciences Bukharaev R. conducted intensive research and achieved great success ([Bukharaev, Suleimanov, O sozdanii...], [Bukharaev, Suleimanov, Semanticheskii...], [Bucharaev]).

Bukharaev R. got fundamental results in probabilistic machines, mathematical models of fundamentally new types of electronic computing machines, and the theory of construction of probable machines and their networks. Independently from Carlisle (USA), he was the first to introduce the concept of the mathematical object (a possible automaton) in the USSR, having built the first example of a language that cannot be represented by any finite automaton. It also described the necessary and sufficient conditions for languages, vocabulary functions, multichannel communication channels, and random code sequences represented by probable automata. R. Bukharaev constructed a complete matrix theory of homomorphism and the equivalence of probable automata.

One of Bukharaev's greatest contributions to the field of probable machine theory and construction is the development of a powerful methodology for research. Based on this methodology, he created a complete theory that allowed him to unravel the deep connections between deterministic and probable automata and classes of mathematical objects, and to solve the problems of optimal synthesis of probabilistic machines by implementing classes of probabilistic algorithms of a given characteristic. Using this methodology, R. Bukharaev and his students developed more than 40 devices to model random codes and processes.

The results of his research in the field of theory and construction of these potential automata are described in two R. Bukharaev's doctoral theses. His first one was in technical sciences: "The Theory of Machine Building to Solve Problems by the Method of Statistical Modeling" (presented in 1968), and his second one was in Physical and Mathematical Sciences: "Languages and Vocabulary Functions in Multiple Probabilistic Automata, Multi-Channel Channels, and Random Sequences" (presented in 1981). The concept of probable machines and algorithms is closely linked to the study of artificial intelligence problems. This area, in particular, is reflected in the development and construction of the conception of a linguistic processor with artificial intelligence elements that provide human communication with computers using natural language.

R. Bukharaev's scientific interests were not limited by these areas of research. He had always been a pioneer in the organization and scientific guidance of the most relevant research areas of new information technologies. These include, first and foremost, the automation of systems and software complexes used for various purposes - the automation system of abstract-mathematical research, based on the electronic computer "MATISS", the automation of the analysis of the answers, entered in the natural language in educational systems, the automation system of the computer projecting the parallel processing of the information. These made it possible to present a system of machine graphics based on unique principles that ensured their efficient use in design.

In R. Bukharaev's scientific activities, a special place is occupied by his work devoted to the computer use of Tatar as a state language. He was the founder and research supervisor of the Shakli Fahm Lab, which was at the forefront of this work. Under his leadership, the standards for the use of the Tatar language in computers were developed and approved in 1996 by a decision of the Cabinet of Ministers of the Republic of Tatarstan. Now his work is successfully continued by his students, doctors and candidates of science, at the Institute of Applied Semiotics of the Tatarstan Academy of Sciences.

R. Bukharaev's work in the field of theory of probable processors and automata has gained international recognition. He was elected to the membership of the International Academy of Nonlinear Sciences. 
Many times he delivered lectures on the theory of probable automata abroad: at the International Mathematical Center named after Banach (Warsaw, twice), at the universities of Berlin, Rostock, Buenos Aires, and at the universities of the cities of Saarbrücken and Hamburg.

R. Bukharaev established his own scientific school, which prepared thirty six candidates of science, six of them presented their doctoral dissertations. Many of his disciples are already heads of departments and scientific disciplines. For many years he was the chairman of the Coordinating Council of KSU on the main scientific area "Mathematical problems and software of automation of intellectual activities". He did a lot of work as a member of the editorial board of the international journal "The News of Higher Schools. Mathematics", as an editor-in-chief of the mathematical editorial board of the Encyclopedia of the Republic of Tatarstan, and as a member of special councils for the defense of candidate and doctoral dissertations. His book, "Fundamentals of Probable Machine Theory", was published in 1985 by the Moscow publishing house "Nauka" and was published in German in the Federal Republic of Germany.

R. Bukharaev effectively worked as a science organizer. The computing center of Kazan University was established on the basis of the laboratory of the Department of Mathematical Analysis, and in 1957 its first head was R. Bukharaev. Due to his creative and organizational activities, the university started a special laboratory and the Department of Cybernetics of the N. Chebotarev Research Institute of Mathematics and Mechanics, the Department of Theoretical Cybernetics, the Faculty of Computational Mathematics and Cybernetics, and the Institute of Electronic Control Machines. At Kazan State University, the Research Laboratory on Artificial Intelligence Problems was established.

For many years he was the chairman of the Scientific Council on the Problem of Complex Cybernetics under the Presidium of the USSR Academy of Sciences on Probable Automata and Their Uses.

He also chaired the Commission on Automation and Computing Technology under the Presidium of the Kazan Branch of the USSR Academy of Sciences and the Republican Committee for Computing Technology under the Council of the Scientific and Technical Society of the TASSR. The team, led by R. Bukharaev, and, personally he made a significant contribution to the implementation of information and communication technolo- gies in Tatarstan, to their Tatarization, to the study and development of the Tatar language using computer technologies. For his great achievements in science and education and his active participation in public affairs he was awarded the State Prize in Science and Technology (2009). Bukharaev was also awarded the badge "Honorary Worker of Higher Professional Education of the Russian Federation" and medals.

Using the words of Tukay, we can describe R. Bukharaev not like a "sunken" scholar, who had made great strides in the field of science, but like a true Tatar intellectual, a multi-talanted personality, and a true mentor. He always took thought for talented young people, taking care of his substitutes and successors. From the first steps of the Selet movement, which is widely known in the Tatar world, he took an active part in attracting children to the world of science, computer science, cybernetics, and artificial intelligence with his fun lessons. Now, after his death, both his work and his name are being continued in his students and youth. In his memory, the annual "Bu-Hakaton" Competition and the R. Bukharaev readings have become a tradition.

\section{References}

Bukharaev, R. G. (1965). Kriterii predstavimosti sobytii $v$ konechnykh veroiatnostnykh avtomatakh [A Criterion for the Representability of Events in Finite Probabilistic Automata]. Doklady AN SSSR, t. 164, No. 2, pp. 289-291. (In Russian)

Bukharaev R. G. (1970). Veroiatnostnye avtomaty [Probabilistic Automata]. 187 p. Kazan', izd-vo Kazan. universiteta. (In Russian)

Bukharaev, R. G. (1985). Osnovy teorii veroiatnostnykh avtomatov [Foundations of the Theory of Probabilistic Automata]. 287 p. Moscow, Nauka. (In Russian)

Bukharaev, R. G. (1978). Veroiatnostnye avtomaty (obzor) [Probabilistic Automata]. Moscow, VINITI, t. 15, pp. 79-122. (In Russian)

Bukharaev, R. G., Zakharov, V. M. (1978). Upravliaemye generatory sluchaynykh kodov [Controlled Generators of Random Codes]. 160 p. Kazan', izd-vo Kazan. Universiteta. (In Russian)

Bukharaev, R. G. (1987). Instrumental'nye dialogovye sistemy [Instrumental Dialogue Systems]. R. G. Bukharaev, A. I. Ienikeev, I. I. Makarov. 110 p. Kazan', izd-vo Kazan. universiteta. (In Russian)

Bukharaev, R. G., Suleimanov, D. Sh. (1986). O sozdanii avtomatizirovannykh obuchaiushchikh sistem $s$ intellektual'nymi vozmozhnostiami [On the Creation of Automated Learning Systems with Intellectual Capabilities]. Kiiev, Naukova Dumka, Kibernetika. No. 3, pp. 42-49. (In Russian) 
Bukharaev, R. G., Suleimanov, D. Sh. (1990). Semanticheskii analiz $v$ voprosno-otvetnykh sistemakh [Semantic Analysis in Question-Answer Systems]. 124 p. Kazan', izd-vo Kazan. universiteta. (In Russian)
Bucharaev, R. G. (1994). Stochastische Automaten [Stochastic Automata]. Stuttgart, Teuner Verlag. (In German)

\title{
РӘИС ГАТА УЛЫ БОХАРАЕВ - ГАЛИМ, МӨГАЛЛИМ, ОСТАЗ
}

\author{
Жәүдәт Шәүкәт улы Сөләйманов, \\ ТР ФАнең "Гамәли семиотика" фәнни-эзләнү институты, \\ Россия, 420111, Казан ш., Сул Болак ур., 36 нчы А йорты, \\ dvdt.slt@gmail.com.
}

Әнис Фоат улы Галимжанов,

Казан федераль университеты, Россия, 420008, Казан ш., Кремль ур., 18 нче йорт, anis_59@mail.ru.

Татарның күренекле галиме Р. Г. Бохараевка, исән булса, быел 91 яшь тулган булыр иде. Аның фәнни мирасы дистәләгән юнәлешләр өчен нигез булып тора, ә күп санлы шәкертләре галим гыйльми эшчәнлегенең төрле тармакларын лаеклы дәвам итәләр.

Рәис Гата улы Бохараев 1929 елның 24 апрелендә Томск шәһәрендә туа. 1947 елда ул Казан шәһәрендәге 2 нче номерлы мәктәпне тәмамлый һәм Казан дәүләт университетының физика-математика факультетына укырга керә hәм ул алдагы тормышын бу югары мәктәп белән бәйли.

Күпкырлы шәхес, талантлы математик, киң карашлы философ булу белән бергә, фәнни фаразлау, гыйльми сиземләү сәләте Рәис Гата улына берничә яңа фәнни юнәлештә, университетта гына түгел, ә бөтен ил, хәтта бөтендөнья масштабында беренчеләр рәтендә булып, нәтижәле эшләр башларга мөмкинлек бирә ([Бухараев, Критерий...], [Бухараев, Вероятностные..., 1970], [Бухараев, Основы...], [Бухараев, Вероятностные..., 1978], [Бухараев, Захаров], [Бухараев, Инструментальные...]). Фәнни кибернетика, ихтимали автоматлар теориясе, ясалма интеллект өлкәләрендә аның житәкчелегендә башланган эзләнүләр һәм гамәли эшләр бүгенге көндә дә Казан федераль университетында һәм Татарстан Фәннәр академисендә уңышлы дәвам итә.

Галим фәнни эшчәнлеген бөек геометр профессор А. П. Норден житәкчелегендә башлый. Геометрия өлкәсендәге тикшеренүләре нигезендә 1955 елда "Биаффин өслекләре теориясе һәм биаксиль пространстволар конгруэнциясе теориясе" дигән темага кандидатлык диссертациясе яклый. Моннан соң ул үзен гыйльми эзләнүләрнең яңа өлкәсе кибернетикага багышлый. Р. Г. Бохараев, математик кибернетика həм информатика өлкәләрендә күп тикшеренүләр башкарып, зур уңышларга ирешә ([Бухараев, Сулейманов, О создании...], [Бухараев, Сулейманов, Семантический...], [Bucharaev]).

Р. Бохараев ихтимали автоматлар, принципиаль яңа типтагы электрон хисаплау машиналарының математик модельләре һәм ихтимали машиналар һәм аларның челтәрләрен төзү теориясе буенча фундаменталь нәтижәләргә ирешә. Ул СССРда беренче булып һәм Карлайлга (АКШ) бәйсез рәвештә бу математик объект (ихтимали автомат. - acc. авт.) төшенчәсен кертә, бернинди дә чикле автомат ярдәмендә күрсәтеп булмый торган телнең беренче мисалын төзи. Галим шулай ук телләр, сүзлек функцияләре, күптактлы элемтә каналлары һәм очраклы кодлар эзлеклелекләренең ихтимали автоматлар белән күрсәтелүләренең кирәкле һәм житәрлек шартларын тасвирлый. Р. Г. Бохараев ихтимали автоматлар гомоморфизмы һәм эквивалентлыгының тулы матрицалы теориясен төзи.

Тикшеренүләр өчен эшләнгән куәтле методология P. Бохараевның ихтимали машиналар теориясе һәм төзелеше өлкәсендәге иң зур хезмәтләренең берсе булып тора. Аның ярдәмендә детерминир һәм ихтимали автоматлар һәм кушымталар өчен бик мөһим булган математик объектлар класслары арасындагы тирәнтен бәйләнешләрне ачарга, бирелгән характеристикалы ихтимали алгоритмнар классларын реализацияләгән 
ихтимали машиналарны оптималь синтезлау мәсьәләләрен чишәргә мөмкинлек биргән теория төзелә. Бу методология нигезендә галим һәм аның шәкертләре тарафыннан очраклы код һәм процессларны модельләү өчен 40тан артык жайланма төзелгән.

Әлеге ихтимали автоматлар теориясе һәм төзелеше өлкәсендәге тикшеренүләренең нәтижәләре Р. Бохараевның ике докторлык диссертациясендә чагылган. Аның беренчесе техник фәннәр буенча: “Статистик модельләү методы буенча мәсьәләләр чишү өчен, машиналар төзү теориясе” (1968 елда якланган), икенчесе физика-математика фәннәре буенча: “Чикле ихтимали автоматларда телләр һәм сүзлек функцияләре, күптактлы каналлар һәм очраклы эзлеклелекләрнең күрсәтелеше” (1981 елда якланган). Ихтимали машиналар һәм алгоритмнар концепциясен галим шәкли фәһем - ясалма интеллект проблемаларын тикшерү белән тыгыз элемтәдә алып бара. Бу юнәлеш, аерым алганда, кешенең санак белән табигый тел кулланып аралашуын тәэмин итүче ясалма интеллект элементлары булган лингвистик процессор концепциясен эшләүдә һәм төзүдә чагылыш тапты.

P. Бохараев гыйльми эшчәнлегенең диапазоны тикшеренүләрнең бу юнәлешләре белән генә чикләнми. Ул һәрвакытта да яңа мәгълүмати технологияләрнең иң актуаль булган тикшеренү юнәлешләрен оештыруда hәм аларны фәнни житәкләүдә пионер булды. Алардан, беренче чиратта, төрле максатта кулланылган систем программ комплекслар "МАТИСС" электрон-хисаплау машинасы нигезендәге абстракт-математик тикшеренуләрне автоматлаштыру системасын; уку-укыту системаларында табигый телдә ирекле форматта кертелгән жавапларны анализлауны автоматлаштыру, информацияне параллель эшкәртүче микропроцессор аппаратураны проектлауны автоматлаштыру системасын; графиканы проектлауда эффектив файдалануны тәэмин итүче уникаль принципларга нигезләнгән машина графикасы системасын күрсәтергә була.

Татар телен дәүләт теле буларак санакта куллануга кертү юнәлеше Р.Г. Бохараев гыйльми эшчәнлегендә аерым урын алып тора. Ул шушы тармакның башында торган “Шәкли Фәһем" лабораториясенә нигез сала һәм фәнни житәкчесе була. Аның житәкчелегендә татар телен санакларда куллану стандартлары эшләнә һәм ул 1996 елда Татарстан Министрлар Кабинеты карары белән раслана. Хәзер галим эшен шәкертләре, докторлар һәм фән кандидатлары, Татарстан Фәннәр академиясенең "Гамәли семиотика" институтында уңышлы дәвам иттерәләр.

Р. Бохараевның ихтимали процессорлар һәм автоматлар теориясе өлкәсендәге хезмәтләре халыкара күләмдә танылу алып, ул Халыкара нәсызыкча фәннәр академиясенең хакыйкый әгъзасы итеп сайлана. Ихтимали автоматлар теориясенә караган лекцияләрен ул чит илләрдә күп тапкырлар, аерым алганда, С. Банах исемендәге Халыкара математик үзәктә (Варшава, 2 тапкыр), Берлин, Росток, БуэносАйрес шәһәрләре университетларында һәм Саарбрюккен һәм Гамбург шәһәрләре университетларында укый.

P. Бохараев үзенең фәнни мәктәбен булдыра, аның тарафыннан 36 фәннәр кандидаты әзерләнә, аларның 6 сы докторлык диссертацияләрен яклый. Галимнең дистәләгән шәкертләре инде үзләре кафедралар һәм фәнни юнәлешләрнең житәкчеләре вазифаларын башкара. Ул күп еллар КДУда “Интеллектуаль эшчәнлекне автоматлаштыруның математик проблемалары һәм программ тәэминаты" дип аталган төп гыйльми юнәлеш буенча Координацион советның рәисе булып тора. Шулай ук озак еллар “Югары уку йортлары хәбәрләре. Математика" халыкара журналының редколлегия әгъзасы, Татарстан Республикасы Энциклопедиясе математик редакциясенең баш редакторы, кандидатлык һәм докторлык диссертацияләрен яклау буенча махсус советларның әгъзасы булып күп эшләр башкара. Аның "Ихтимали автоматлар теориясе нигезләре" китабы 1985 елда Мәскәүдәге "Наука" нәшриятында басылып чыга һәм Германия Федератив Республикасында немец телендә нәшер ителә.

Атаклы галим югары мәктәптә фәнне оештыручы буларак та нәтижәле эшләр башкара. Казан университетының Исәпләү үзәге механика-математика факультетының математик анализ кафедрасының лабораториясе нигезендә төзелә. Аның беренче житәкчесе итеп 1957 елда Р. Бохараев билгеләнә. Галимнең ижади һәм оештыру активлыгы нәтижәсендә университетта махсус лаборатория һәм Н. Г. Чеботарев исемендәге Математика һәм механика фәнни-тикшерену институтының кибернетика бүлеге, исәпләү математикасы һәм кибернетика факультетының 
теоретик кибернетика кафедрасы, Казан университеты каршындагы Электрон идарә машиналары институты (аның нигезендә сонрак Фәннәр академиясенең Гамәли информатика институтының Казандагы филиалы барлыкка килде. - acc. aвm.), ТР ФАнең һәм КДУның “Шәкли Фәһем” (Ясалма интеллект проблемалары) уртак фәннитикшеренү лабораториясе төзелә.

Р. Бохараев күп еллар СССР ФАнең Президиумы каршындагы "Кибернетика" комплекслы проблемасы буенча Фәнни Советның ихтимали автоматлар һәм аларның кулланылышлары аскомиссиясенең рәисе вазифасын башкара. Шулай ук СССР ФАнең Казан филиалы Президиумы каршындагы автоматлаштыру һәм исәпләу техникасы комиссиясен һәм ТАССР фәнни-техник жәмгыяте Советы каршындагы исәпләу техникасы буенча республика комитетын житәкли. Бу коллектив һәм ул шәхсән үзе Татарстанда инфокоммуникацион технологияләрне гамәлгә кертү, аларны татарчалаштыру, санак технологияләре кулланып татар телен өйрәнү һәм үстерү юнәлешләрендә житди өлеш керттеләр. Әлеге юнәлештәге зур уңышлары өчен Бохараев Фән һәм техника өлкәсендәге Дәүләт премиясенә лаек булды (2009). Фәндәге hәм мәгариф өлкәсендәге уңышлары, жәмәгать эшләрендә актив катнашуы өчен "РФнең югары профессиональ белем биру мактаулы хезмәткәре" билгесе һәм медальләре белән бүләкләнде.

Г. Тукай образы белән әйтсәк, Р. Бохараев фән өлкәсендә зур уңышларга ирешкән “коеп куйган” галим генә түгел, чын татар зыялысы, күпкырлы шәхес тә, чын остаз да иде. Ул hәрчак сәләтле яшьләргә бик игътибарлы булды, үзенең алмашчылары, дәвамчылары булуны кайгыртып яшәде. Татар дөньясында киң танылган “Сәләт” хәрәкәтенең беренче адымнарыннан, шунда актив катнашып, үзенең мавыктыргыч дәресләре белән балаларны фән дөньясына, санаклар, кибернетика, ясалма интеллект фәннәре дөньясына жәлеп итте. Хәзер инде, остазлары Р. Г. Бохараевның вафатыннан соң, аның эшләре дә, исеме дә укучыларында, яшьләрдә дәвам итә. Рәис Гатич истәлегенә багышлап, һәр елны "Бу-Хакатон" конкурсы һәм "Р. Г. Бохараев укулары” уздыру традициягә әверелде.

\section{Әдәбият}

Бухараев Р.Г. Критерий представимости событий в конечных вероятностных автоматах // Доклады АН СССР, 1965, т. 164, № 2. С. 289-291.

Бухараев Р.Г. Вероятностные автоматы. Казань: Изд-во Казан. университета, 1970. 187 с.

Бухараев Р.Г. Основы теории вероятностных автоматов. М.: Наука, 1985. 287 с.

Бухараев Р.Г. Вероятностные автоматы (обзор) // М.: ВИНИТИ, 1978, т. 15. С. 79-122.

Бухараев Р.Г., Захаров В.М. Управляемые генераторы случайных кодов // Казань: Изд-во Казан. университета, 1978. 160 с.

Бухараев Р.Г. Инструментальные диалоговые системы / Р.Г. Бухараев, А.И. Еникеев, И.И. Макаров // Казань: Изд-во Казан. университета, 1987. $110 \mathrm{c}$.

Бухараев Р.Г., Сулейманов Д.Ш. О создании автоматизированных обучающих систем с интеллектуальными возможностями // Киев, Наукова Думка, Кибернетика, 1986, № 3. С. 42-49.

Бухараев Р.Г., Сулейманов Д.Ш. Семантический анализ в вопросно-ответных системах. Казань: Издво Казан. университета, 1990, 124 с.

Bucharaev R.G. Stochstische Automaten // Stuttgart, Teuner Verlag, 1994 (немец телендә). 